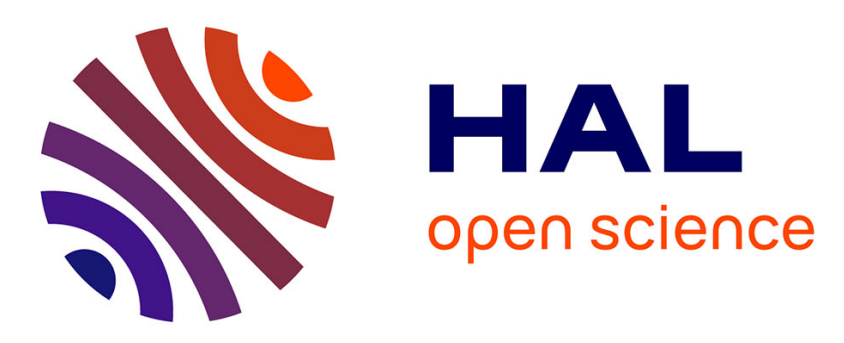

\title{
DNA methylation of polycomb group target genes in cores taken from breast cancer centre and periphery
}

Evangelia-Ourania Fourkala, Cornelia Hauser-Kronberger, Sophia Apostolidou, Matthew Burnell, Allison Jones, Johannes Grall, Roland Reitsamer, Heidi Fiegl, Ian Jacobs, Usha Menon, et al.

\section{To cite this version:}

Evangelia-Ourania Fourkala, Cornelia Hauser-Kronberger, Sophia Apostolidou, Matthew Burnell, Allison Jones, et al.. DNA methylation of polycomb group target genes in cores taken from breast cancer centre and periphery. Breast Cancer Research and Treatment, 2009, 120 (2), pp.345-355. 10.1007/s10549-009-0384-3 . hal-00535355

\section{HAL Id: hal-00535355 \\ https://hal.science/hal-00535355}

Submitted on 11 Nov 2010

HAL is a multi-disciplinary open access archive for the deposit and dissemination of scientific research documents, whether they are published or not. The documents may come from teaching and research institutions in France or abroad, or from public or private research centers.
L'archive ouverte pluridisciplinaire HAL, est destinée au dépôt et à la diffusion de documents scientifiques de niveau recherche, publiés ou non, émanant des établissements d'enseignement et de recherche français ou étrangers, des laboratoires publics ou privés. 


\title{
DNA methylation of polycomb group target genes in cores taken from breast cancer centre and periphery
}

\author{
Evangelia-Ourania Fourkala $\cdot$ Cornelia Hauser-Kronberger · Sophia Apostolidou • \\ Matthew Burnell · Allison Jones · Johannes Grall · Roland Reitsamer · \\ Heidi Fiegl · Ian Jacobs · Usha Menon · Martin Widschwendter
}

Received: 14 February 2009/ Accepted: 19 March 2009/Published online: 8 April 2009

(C) Springer Science+Business Media, LLC. 2009

\begin{abstract}
We previously demonstrated that methylation of neugogenic differentiation 1 (NEUROD1) gene, a polycomb group target (PCGT) gene is a predictor of response to neoadjuvant chemotherapy in breast cancer. Here, we address the question whether NEUROD1 methylation provides clinical information independent from its expression level, and whether PCGT methylation is homogeneous in breast cancer. We examined: (1) NEURODI methylation and mRNA expression in 9 breast cancer cell lines and 63 tumour specimens, (2) DNA methylation in a training set of 55 PCGT genes taken from the centre (TUC) and periphery (TUP) of 15 breast cancer specimens, and compared this
\end{abstract}

The authors Evangelia-Ourania Fourkala and Cornelia Hauser-Kronberger are equally contributed this work.

Electronic supplementary material The online version of this article (doi:10.1007/s10549-009-0384-3) contains supplementary material, which is available to authorized users.

E.-O. Fourkala $\cdot$ S. Apostolidou $\cdot$ M. Burnell $\cdot$ A. Jones .

I. Jacobs · U. Menon · M. Widschwendter $(\bowtie)$

Department of Gynaecological Oncology, Institute for Women's

Health, University College London, 1st Floor, Maple House,

149 Tottenham Court Road, London W1T 7DN, UK

e-mail: M.Widschwendter@ucl.ac.uk

C. Hauser-Kronberger · J. Grall

Department of Pathology, Breast Centre Salzburg, Paracelsus Private Medical University Salzburg, Muellner Hauptstrasse 48, 5020 Salzburg, Austria

R. Reitsamer

Department of Senology, Breast Centre Salzburg, Paracelsus Private Medical University Salzburg, Muellner Hauptstrasse 48, 5020 Salzburg, Austria

H. Fiegl

Department of Gynaecology and Obstetrics, Medical University Innsbruck, Innsbruck, Austria with 22 non neoplastic controls, and finally, (3) validated statistically significant genes in an independent set of 20 cases versus 18 controls. 8/9 cell lines demonstrated $N E U$ RODI methylation, whereas, there was only one cell-line that showed NEURODI expression. There was no association between methylation and expression in breast tumour specimens, with only $14 \%$ exhibiting NEURODI expression. Of the 55 PCGT genes analysed, 24\% (13/55) were shown to be cancer specific $(p<0.05)$ with a receiver-operating-characteristic (ROC) area-under-the-curve (AUC) of $>0.7$ (range $0.71-0.95$ ). DNA methylation accurately predicted the presence of cancer in both TUC and TUP. DNA methylation of PCGT genes predicts the presence of breast cancer and is not subject to tumour heterogeneity. Further work will reveal if methylation of PCGT genes will serve as a robust means for the clinical detection and assessment of breast cancer.

Keywords DNA methylation - Breast cancer . Intra-tumour heterogeneity

\section{Introduction}

Breast cancer is the most common female cancer. The overall lifetime risk of developing an invasive breast cancer is $10 \%$. Despite progress in early detection and treatment, breast cancer still accounts for the second largest number of cancer related deaths in the western world [1]. Therefore, identification of novel molecular markers with the potential for optimal disease management and improved survival rates is essential.

During the last decade, a huge emphasis has been given to the identification of genetic changes and expression profiles that correlate with clinical characteristics of the 
disease, in an attempt to discover genetic markers predicting prognosis and response to treatment [2-6]. Many of these studies have been based on a single sample from within the tumour, assuming that this single region reflects the genetic signature of the whole cancer. However, there are increasing reports of the presence of intra-tumour heterogeneity and its effect on expression profiling in several cancer types [7-13], including breast cancer [14, 15].

Intra-tumour heterogeneity is the result of a multifactorial microenvironment which exhibits a zonal heterogeneity from central to peripheral regions [16]. Studies comparing the central with the peripheral zone have identified expression of different molecules within these regions. In the centre, which is characterised by hypoxic conditions, genes such as vascular endothelial growth factor $(V E G F)$ have been shown to be regulated and molecules such as the matrix metalloproteinases (MMPs) are overexpressed. In the tumour periphery, which is localised at the stromal border, forming the biologically active invasion front and cancer stem cell reservoir, molecules such as E-cadherin have been shown to be down-regulated [17, 18]. Even, for oestrogen (ER) and progesterone receptors (PR), which are the most significant markers in treatment strategies, there is conflicting data with studies also reporting to be differently expressed in different regions within the tumour [19-21]. This has led to an increased emphasis for the need to study more than one part of the tumour to ensure the generation of accurate and reproducible data, especially as these data are used to guide patient management. Based on these observations we suggest that the problem of intratumour heterogeneity may be overcome by studying DNA based alterations, such as epigenetic changes, specifically DNA methylation, which may not be affected by the zonal microenvironment of the tumour.

Epigenetic modifications, and in particular DNA methylation, is known to be an early event in carcinogenesis and to precede major genetic changes leading to cancer. The main differences between epigenetic and genetic alterations are that the former occuring at a higher frequency, are reversible upon treatment with pharmacological agents, and arise at defined regions within a gene $[22,23]$. These characteristics make them an attractive alternative for cancer detection and assessment [24, 25]. Several studies have shown multiple genes to be differently methylated in normal versus tumour tissue [26-29]. Recently, we and others demonstrated that stem cell polycomb group-target (PCGT) genes are more likely to have cancer specific promoter DNA hypermethylation than non-PCGT genes [30-32]. Furthermore, we showed that hypermethylation of NEURODI within pretreatment core biopsies preferentially discriminated between neoplastic and non-neoplastic breast tissue samples, and was associated with a favourable response to treatment [27]. Given the data showing that expression profiles are affected by intra-tumour heterogeneity, it is essential to establish that the methylation profile of the core biopsy is representative of the entire tumour.

In this study, we initially analysed the expression and DNA methylation profile of NEUROD1 in 9 breast cancer cell lines and 63 frozen breast cancer tissues. Based on the results we postulated that a DNA methylation signature may carry information independently from the expression profile of the tumour. In order to further investigate both the predictive role and homogeneity of PCGT gene methylation in breast cancer, we compared methylation levels using MethyLight, a highly sensitive real-time PCR methylation assay [33], of PCGT genes in paraffin embedded breast cancer tissue biopsies taken from the central (TUC) and peripheral (TUP) parts of the tumour and compared this with non-neoplastic breast tissue.

\section{Materials and methods}

\section{Subjects}

The project was jointly approved by the UCL/UCLH Research Ethics Committee, University London College and by the University of Salzburg. The samples were collected at the Department of Pathology, Paracelsus Private Medical University Salzburg (Salzburg, Austria). Clinical and pathologic data were stored in a database in accordance with hospital privacy regulations. For the mRNA analysis, frozen breast tissue samples were collected from 63 patients with breast cancer. The breast cancer specimens were obtained immediately after resection of the breast or lumpectomy, and therefore prior to treatment. The specimens were processed by the pathologist and part of the tissue was pulverized under liquid nitrogen and stored at $-70^{\circ} \mathrm{C}$. Clinicopathological features of these samples have previously been reported [27]. For the PCGT gene methylation analysis, tissue samples were collected from postmenopausal women undergoing surgery for ER+ve breast cancer or benign breast changes. Core biopsies were dissected from the centre of pT1 and pT2 invasive ductal carcinoma and from the peripheral cancer stromal border, as shown in Supplementary S1. Relevant tissue areas from tumours at least $1 \mathrm{~cm}$ in diameter were selected on Haematoxylin and Eosin (H\&E) slides and used to guide dissection from the paraffin block. For DNA extraction, $3 \mathrm{~mm}$ diameter core punches were used. The samples were a priori separated into two sets: training and validation. Although grading $(p=0.073)$ and sentinel status $(p=0.072) p$ values almost reached statistical significance, no other clinicopathological feature demonstrated significant differences $(p$ values $<0.05)$ between the two sets as shown in Table 1 . 
Table 1 Clinicopathological features are shown for the breast cancer cases that tissue was taken from the centre and periphery for both training and validation set

\begin{tabular}{llrcc}
\hline Clinicopathological features & $\begin{array}{l}\text { Training } \\
\text { set }\end{array}$ & $\begin{array}{l}\text { Validation } \\
\text { set }\end{array}$ & $p$ value \\
\hline Age & & 60 & 59.55 & 0.298 \\
Histological & IDC $^{\mathrm{a}}$ & 5 & 8 & 0.227 \\
type & IDC + DCIS $^{\mathrm{b}}$ & 10 & 12 & \\
Grading & I & 1 & 0 & 0.073 \\
& II & 10 & 17 & \\
& III & 4 & 3 & \\
Staging & 1 & 11 & 11 & 0.096 \\
& 2 & 4 & 9 & \\
PR & Positive & 12 & 15 & 0.237 \\
& Negative & 3 & 5 & \\
HER2+ & 1 & 7 & 5 & 0.121 \\
& 2 & 1 & 3 & \\
& 0 & 7 & 12 & \\
Sentinel & Positive & 5 & 9 & 0.072 \\
& Negative & 15 & 11 & \\
\hline
\end{tabular}

${ }^{a}$ Invasive ductal carcinoma

b Ductal carcinoma in situ

Cell-lines, culture conditions and reagents

Human breast cancer cell lines BT-20, ZR-75-1, MCF7, MDA-MB-231, T-47D, and SK-BR-3 were obtained from the American type culture collection (ATCC) and cultured according to the recommended guidelines. The following cell lines were generously provided: HBL-100 from NE Hynes, F Miescher Institute, Basle, Switzerland and Hs 578T from GC Buehring, School of Public Health, Berkley, CA, USA and were cultured in Dulbecco's modified eagle medium (DMEM; Gibco Invitrogen Corporation, Lofer, Austria) containing $10 \%$ fetal bovine serum (Biochrom AG, Berlin, Germany).

\section{RNA isolation and RT-PCR}

Total cellular RNA was extracted from the tumour specimens using the acid guanidium thiocyanate-phenolchloroform method, and reverse transcription was performed as previously described [34, 35]. Primers and probes for NEUROD1 RT-PCR analysis were purchased from Applied Biosystems (Applied Biosystems Assay ID: Hs00159598_m1). Primers and probes for the TATA boxbinding protein (TBP; a component of the DNA-binding protein complex TFIID as endogenous RNA control) were used according to Bieche et al. [36]. Real-time PCR was performed using an ABI Prism 7900HT Detection System (Applied Biosystems, Foster City, CA). The standard curves were generated using serial dilutions of standard
cDNA derived from the HBL-100 breast carcinoma cellline.

DNA isolation, bisulphite modification and analysis of DNA methylation

DNA was extracted using the QIAGEN/QIA-amp Tissue kit as previously described [27]. Specific criteria were set up to select the eligible samples to perform for the analysis as follows: The quality of the genomic DNA was checked by two methods: (1) quantification and (2) real-time PCR using three housekeeping genes collagen 2A1 (COL2Al), $\beta$-actin $(A C T B)$ and glyceraldehydes 3-phosphate dehydrogenase $(G A P D H)$ (primer sequences are provided in Supplemental Table S1). The samples that had sufficient DNA for the purpose of analysis and a mid-exponential cycle threshold (Ct) value of $<36$, were included in the study (data not shown). The eligible samples were bisulphite modified based on the manufacturer's instructions (Zymo Research, Orange, CA) and MethyLight analysis was performed as described previously [27]. The specificity of the reactions for methylated DNA was confirmed using SssI (New England Biolabs, UK) treated human white blood cell DNA (heavily methylated). The percentage of fully methylated molecules at a specific locus, as defined by percentage of methylated reference (PMR), was calculated by dividing the GENE:COL2A1 ratio of a sample by the GENE:COL2AI ratio of the SSSItreated human white blood cell DNA, and multiplying by 100 . The analysis was performed blinded, and cases and controls were randomly mixed during bisulphite treatment and realtime PCR. The concentration of bisulphite modified DNA (assessed by the level of the reference gene COL2A1) was the same between cases and controls (data not shown). A detailed list of the nucleotide sequences for MethyLight primers and probes in the promoter or $5^{\prime}$ end region for all analysed loci is provided in supplemental Table $\mathrm{S} 1$.

\section{Statistics}

Statistical analysis was carried out using a computer assisted program-SPSS version 12.0.1, Chicago, IL. For both training and validation sets, for each gene the percent of non-zero results, the median and the $p$ values from the Mann-Whitney test, were calculated. The genes in both training and validation sets were also assessed using receiver-operating-characteristic (ROC) curves and the area-under-the curve (AUC) value. When a gene was denoted with a 'reverse decision rule' this meant that the higher the methylation value the more likely the subject would be a control rather than a case. In order to assess if there is a difference between the TUC and TUP groups, a non-parametric paired test (Wilcoxon rank test) was carried out comparing the rank order of values for TUC versus 
TUP. Spearman correlation analysis was performed in order to examine any association between the two zones, tumour taken from the centre and periphery.

\section{Results}

NEUROD1 methylation does not correlate with NEURODI mRNA expression

Based on two of our recent studies, we showed that $N E U$ ROD1 was one of the best discriminators between breast cancer and non neoplastic tissue samples [30] and that methylated NEUROD1 promoter could be a good predictive marker for chemosensitivity in breast cancer [27]. Since cancer specific methylation of some of the PCGT genes, such as myogenic differentiation 1 (MYODI) and neugogenin 1 (NEUROG1) has been shown not to be associated with expression in epithelial cancers [30], we wanted to investigate the association of the methylation and expression profile of NEUROD1 in breast cancer. Therefore, we analysed and compared NEURODl methylation and NEUROD1 mRNA expression in a panel of nine human breast cancer cell lines. As it is illustrated in Figure 1, from the 9 tested cell lines only 1 expressed NEUROD1 whereas, NEUROD1 methylation was observed in 8 out of 9 cell lines. To further examine this observation, we analysed $N E U$ $R O D 1$ expression and methylation of 63 frozen breast cancer tissue samples. The experiments were performed in
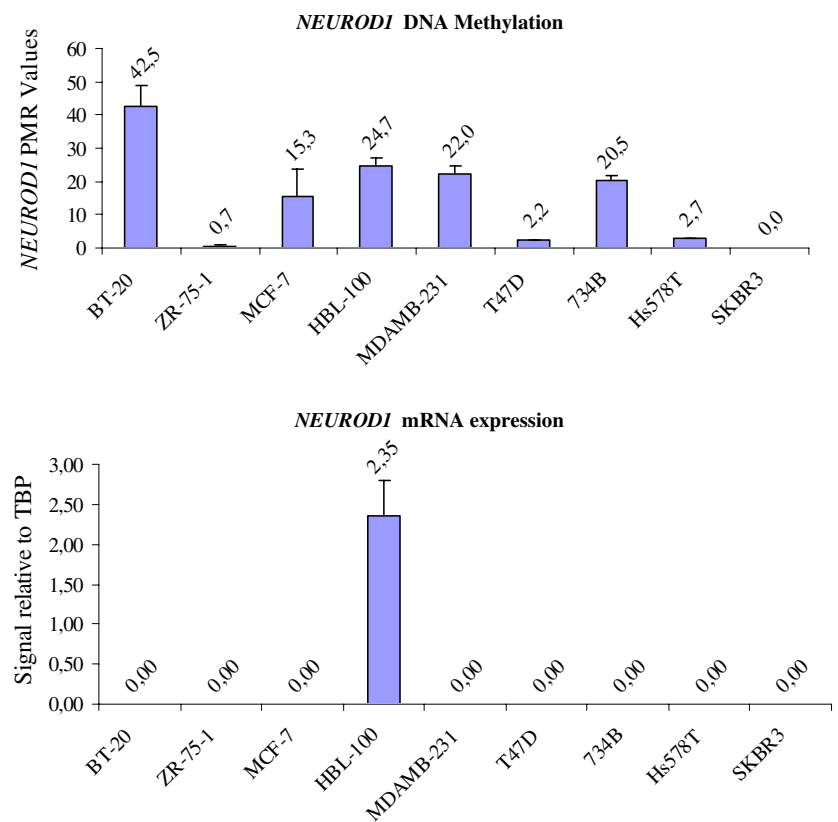

Fig. 1 NEUROD1 methylation and mRNA expression in breast cancer cell lines. Nine different breast cancer cell lines were tested for their DNA methylation and mRNA status for NEURODI triplicate and, when at least two signals of the analysis had given a negative value, the expression was considered as zero. As is seen in supplemental Table S3, the majority of the cases, 54/63 (85.7\%) did not express NEUROD1 in contrast to NEUROD1 methylation, which was detected in all cases with a PMR value ranging from 0.05 to 633 .

PCGT genes can predict the presence of breast cancer

In order to further investigate the methylation level changes of the PCGT genes in breast cancer we analysed a sample set consisting of TUC and TUP tissues from 35 postmenopausal women with $\mathrm{ER}+\mathrm{ve}$ breast cancer and compared these with non neoplastic breast tissue from 40 postmenopausal women who had undergone surgery for benign breast changes. The samples were divided into a training set consisting of 15 cases and 22 controls, and a validation set of 20 cases and 18 controls.

In the training set, we examined methylation of 55 PCGT genes in 14 TUC and 15 TUP samples and 22 controls. 24\% (13 out of 55) of the genes analysed were cancer specific $(p<0.05)$, being more frequently methylated in tumour samples when compared with non neoplastic tissues as illustrated in Table 2. To test the hypothesis that the selected genes are cancer predictors, we assessed them by ROC analysis as seen in Table 3 . In this table, for both TUC and TUP groups, the $p$ values given reflect whether the AUCs are significantly different from 0.5 (a straight line from bottom left to top right corners, implying a decision rule no better than chance). The predictive value of the 13 genes was statistically significant showing an AUC range of 0.667-0.930 for the TUC samples and 0.714-0.955 for the TUP samples.

To further validate these findings, we analysed in an independent validation set consisting of 19 TUC, 20 TUP samples and 18 controls, the 13 PCGT genes from the training set that had a $p<0.05$ in the Mann-Whitney analysis for both TUC and TUP. All 13 genes (Table 4) were confirmed and were shown to be statistically significant in the validation set $(p<0.05)$. We calculated the predictive potential of these 13 genes by ROC analysis as it is illustrated in Table 5. Interestingly, even though the sample size is low, the results were consistent and the same panel of genes that were shown to be statistically significant with the Mann-Whitney test also had a statistically significant AUC value $(p<0.05)$.

DNA methylation of PCGT genes is not affected by intra-tumour heterogeneity

Even though we show methylation levels of specific genes to be comparable between selected TUC and TUP tissue samples in both the training and validation sets, there were also 
Table 2 Summary statistics of controls versus tumour taken from the centre (TUC) and tumour taken from the periphery (TUP) from the breast cancer cases analysed in the training set

\begin{tabular}{|c|c|c|c|c|c|c|c|c|c|}
\hline \multirow[t]{2}{*}{ Genes } & \multicolumn{2}{|c|}{ Control $(n=22)$} & \multicolumn{3}{|c|}{ TUC $(n=15)$} & \multicolumn{4}{|l|}{ TUP $(n=14)$} \\
\hline & Positive (\%) & Median PMR & Positive (\%) & Median PMR & $p$ value & Positive (\%) & Median PMR & $p$ value & $p$ value (rank) \\
\hline HOXD9 & 77.3 & 0.01 & 100 & 1.42 & 0.000 & 100 & 2.48 & 0.000 & 1 \\
\hline HOXA7 & 90.9 & 0.28 & 100 & 5.39 & 0.000 & 100 & 3.96 & 0.000 & 3 \\
\hline PENK & 9.1 & 0.00 & 73.3 & 0.09 & 0.000 & 78.6 & 4.22 & 0.000 & 2 \\
\hline TMEFF2 & 50 & 0.00 & 93.3 & 8.96 & 0.000 & 92.9 & 7.06 & 0.000 & 5 \\
\hline HOXA1 & 59.1 & 0.03 & 80 & 11.74 & 0.002 & 85.7 & 11.31 & 0.000 & 6 \\
\hline MT1A & 95.5 & 69.92 & 100 & 28.72 & 0.003 & 100 & 19.20 & 0.003 & 15 \\
\hline$C R A B P 1$ & 0 & - & 33.3 & 0.00 & 0.004 & 42.9 & 0.00 & 0.001 & 9 \\
\hline GATA4 & 22.7 & 0.00 & 60 & 0.11 & 0.007 & 28.6 & 0.00 & 0.609 & 35 \\
\hline HOXD11 & 63.6 & 0.75 & 80 & 17.53 & 0.007 & 92.9 & 35.48 & 0.000 & 8 \\
\hline HOXD12 & 54.5 & 0.03 & 73.3 & 10.12 & 0.010 & 85.7 & 7.75 & 0.002 & 12 \\
\hline NEUROD1 & 54.5 & 0.00 & 73.3 & 0.39 & 0.020 & 78.6 & 5.19 & 0.002 & 13 \\
\hline$G A D 1$ & 100 & 0.72 & 100 & 2.57 & 0.020 & 100 & 4.33 & 0.000 & 7 \\
\hline НОХА13 & 54.5 & 1.14 & 66.7 & 177.49 & 0.021 & 100 & 181.40 & 0.000 & 4 \\
\hline PITX2 (II) & 72.7 & 0.26 & 73.3 & 4.33 & 0.029 & 85.7 & 10.64 & 0.001 & 10 \\
\hline$H I C 1$ & 63.6 & 28.33 & 100 & 42.58 & 0.043 & 100 & 31.32 & 0.054 & 22 \\
\hline$P G R$ & 23.8 & 0.00 & 0 & - & 0.045 & 21.4 & 0.00 & 0.680 & 39 \\
\hline HOXD8 & 63.6 & 0.18 & 80 & 4.57 & 0.052 & 64.3 & 7.04 & 0.111 & 28 \\
\hline ITGA4 & 0 & - & 13.3 & 0.00 & 0.083 & 28.6 & 0.00 & 0.009 & 17 \\
\hline PITX2 (I) & 0 & - & 13.3 & 0.00 & 0.083 & 28.6 & 0.00 & 0.009 & 18 \\
\hline$C A C N A 1 G$ & 0 & - & 13.3 & 0.00 & 0.083 & 14.3 & 0.00 & 0.072 & 24 \\
\hline TWIST & 13.6 & 0.00 & 33.3 & 0.00 & 0.086 & 14.3 & 0.00 & 0.829 & 44 \\
\hline MT3 & 77.3 & 0.07 & 46.7 & 0.00 & 0.107 & 57.1 & 0.00 & 0.041 & 21 \\
\hline$E B F 3(D K F Z)$ & 4.5 & 0.00 & 20 & 0.00 & 0.121 & 42.9 & 0.00 & 0.004 & 16 \\
\hline GABRA2 & 4.5 & 0.00 & 20 & 0.00 & 0.136 & 21.4 & 0.00 & 0.115 & 29 \\
\hline$D L C 1$ & 13.6 & 0.00 & 0 & - & 0.142 & 14.3 & 0.00 & 0.957 & 50 \\
\hline GATA5 & 13.6 & 0.00 & 33.3 & 0.00 & 0.144 & 50 & 0.02 & 0.010 & 19 \\
\hline HOXА11 & 100 & 26.31 & 100 & 19.15 & 0.146 & 100 & 19.77 & 0.092 & 27 \\
\hline $\mathrm{CDH} 13$ & 13.6 & 0.00 & 33.3 & 0.00 & 0.156 & 14.3 & 0.00 & 1.000 & 55 \\
\hline SFRP4 & 50 & 0.00 & 33.3 & 0.00 & 0.171 & 21.4 & 0.00 & 0.057 & 23 \\
\hline NEUROD2 & 59.1 & 0.02 & 60 & 2.34 & 0.189 & 85.7 & 7.14 & 0.001 & 11 \\
\hline ESRl & 50 & 0.00 & 20 & 0.00 & 0.201 & 14.3 & 0.00 & 0.024 & 20 \\
\hline HOXB7 & 77.3 & 0.02 & 53.3 & 0.00 & 0.202 & 78.6 & 0.02 & 0.636 & 37 \\
\hline NEUROG1 & 0 & - & 6.7 & 0.00 & 0.226 & 14.3 & 0.00 & 0.072 & 26 \\
\hline НОХА 6 & 59.1 & 2.21 & 40 & 0.00 & 0.230 & 42.9 & 0.00 & 0.410 & 33 \\
\hline SLC6A2O & 9.1 & 0.00 & 0 & - & 0.236 & 7.1 & 0.00 & 0.892 & 47 \\
\hline SFRP1 & 45.5 & 0.00 & 26.7 & 0.00 & 0.242 & 35.7 & 0.00 & 0.885 & 46 \\
\hline ZВТВ16 & 54.5 & 0.00 & 33.3 & 0.00 & 0.266 & 28.6 & 0.00 & 0.269 & 31 \\
\hline НOХА10 & 95.5 & 2.91 & 80 & 7.13 & 0.300 & 85.7 & 5.03 & 0.626 & 36 \\
\hline$D C C$ & 4.5 & 0.00 & 13.3 & 0.00 & 0.311 & 7.1 & 0.00 & 0.713 & 41 \\
\hline SLIT2 & 63.6 & 0.12 & 46.7 & 0.00 & 0.317 & 50 & 0.02 & 0.637 & 38 \\
\hline$I G F 2$ & 4.5 & 0.00 & 13.3 & 0.00 & 0.343 & 7.1 & 0.00 & 0.713 & 40 \\
\hline HOXC9 & 18.2 & 0.00 & 6.7 & 0.00 & 0.376 & 7.1 & 0.00 & 0.331 & 32 \\
\hline GDNF & 18.2 & 0.00 & 6.7 & 0.00 & 0.376 & 14.3 & 0.00 & 0.764 & 43 \\
\hline TITF1 & 18.2 & 0.00 & 6.7 & 0.00 & 0.376 & 14.3 & 0.00 & 0.920 & 48 \\
\hline НОХА9 & 100 & 11.88 & 86.7 & 7.74 & 0.404 & 100 & 11.52 & 1.000 & 54 \\
\hline$C Y P 27 B 1$ & 100 & 4.86 & 100 & 4.65 & 0.458 & 0 & 6.34 & 0.183 & 30 \\
\hline
\end{tabular}


Table 2 continued

\begin{tabular}{|c|c|c|c|c|c|c|c|c|c|}
\hline \multirow[t]{2}{*}{ Genes } & \multicolumn{2}{|c|}{ Control $(n=22)$} & \multicolumn{3}{|c|}{ TUC $(n=15)$} & \multicolumn{4}{|l|}{ TUP $(n=14)$} \\
\hline & Positive (\%) & Median PMR & Positive (\%) & Median PMR & $p$ value & Positive (\%) & Median PMR & $p$ value & $p$ value (rank) \\
\hline MYOD1 & 22.7 & 0.00 & 26.7 & 0.00 & 0.498 & 64.3 & 0.21 & 0.003 & 14 \\
\hline SFRP5 & 81.8 & 2.43 & 60 & 0.63 & 0.708 & 71.4 & 1.54 & 0.744 & 42 \\
\hline$C Y P 1 B 1$ & 4.5 & 0.00 & 6.7 & 0.00 & 0.752 & 0 & - & 0.425 & 34 \\
\hline$C A L C A$ & 45.5 & 0.00 & 40 & 0.00 & 0.784 & 35.7 & 0.00 & 0.942 & 49 \\
\hline FLJ39739 & 50 & 0.00 & 33.3 & 0.00 & 0.973 & 35.7 & 0.00 & 0.873 & 45 \\
\hline GATA3 & 0 & - & 0 & - & 1.000 & 14.3 & 0.00 & 0.072 & 25 \\
\hline PYCARD & 0 & - & 0 & - & 1.000 & 0 & - & 1.000 & 51 \\
\hline$T P 73$ & 0 & - & 0 & - & 1.000 & 0 & - & 1.000 & 52 \\
\hline BCL22 & 0 & - & 0 & - & 1.000 & 0 & - & 1.000 & 53 \\
\hline
\end{tabular}

$p$ value from the Mann-Whitney test for each gene is provided (significant $p$ value less than 0.05 ). The genes were ordered according to the rank of the $p$ value for the test of TUC versus control, and a further column for the TUP group gave the rank order value for the TUP versus control group to facilitate comparison between tests. Values in bold are the $p$ values of the 13 cancer specific genes that were further tested

$P M R$ Percentage of methylated reference

Table 3 Receiver operating characteristic (ROC) analysis for both TUC and TUP in training set

\begin{tabular}{|c|c|c|c|c|c|c|c|c|c|}
\hline \multirow[t]{2}{*}{ Genes } & \multicolumn{4}{|l|}{ TUC } & \multicolumn{5}{|l|}{ TUP } \\
\hline & AUC & $95 \%$ CI lower & 95\% CI upper & $p$ value & AUC & $95 \%$ CI lower & $95 \%$ CI upper & $p$ value & Rank \\
\hline$H O X D 9$ & 0.930 & 0.852 & 1.008 & 0.000 & 0.955 & 0.894 & 1.015 & 0.000 & 5 \\
\hline HOXA7 & 0.891 & 0.788 & 0.993 & 0.000 & 0.935 & 0.859 & 1.011 & 0.000 & 11 \\
\hline$T M E F F 2$ & 0.853 & 0.719 & 0.987 & 0.000 & 0.888 & 0.767 & 1.009 & 0.000 & 9 \\
\hline PENK & 0.830 & 0.682 & 0.979 & 0.001 & 0.883 & 0.745 & 1.021 & 0.000 & 10 \\
\hline HOXA1 & 0.792 & 0.619 & 0.966 & 0.003 & 0.867 & 0.715 & 1.019 & 0.000 & 1 \\
\hline$M T 1 A^{*}$ & 0.788 & 0.051 & 0.373 & 0.003 & 0.795 & 0.048 & 0.361 & 0.003 & 13 \\
\hline HOXD11 & 0.761 & 0.584 & 0.937 & 0.008 & 0.860 & 0.726 & 0.994 & 0.000 & 6 \\
\hline HOXD12 & 0.745 & 0.564 & 0.927 & 0.012 & 0.808 & 0.650 & 0.967 & 0.002 & 12 \\
\hline$G A D 1$ & 0.727 & 0.557 & 0.897 & 0.020 & 0.870 & 0.733 & 1.007 & 0.000 & 2 \\
\hline NEUROD1 & 0.721 & 0.540 & 0.902 & 0.024 & 0.805 & 0.633 & 0.977 & 0.002 & 4 \\
\hline HOXА13 & 0.718 & 0.526 & 0.910 & 0.026 & 0.922 & 0.835 & 1.009 & 0.000 & 3 \\
\hline PITX2 (II) & 0.712 & 0.513 & 0.911 & 0.030 & 0.825 & 0.656 & 0.993 & 0.001 & 7 \\
\hline$C R A B P 1$ & 0.667 & 0.477 & 0.856 & 0.089 & 0.714 & 0.526 & 0.903 & 0.032 & 8 \\
\hline
\end{tabular}

TUC Tumour taken from the centre, TUP Tumour taken from the periphery, AUC Area under the curve, CI Confidence interval

The performance of each gene as a predictor of breast cancer was assessed using ROC curves and the AUC value. The genes were ordered according to the rank of the $p$ value for the test of TUC and TUP versus control. Significance required a $p$ value of less than 0.05

* 'Reverse decision rule' applied means that the higher the methylation value, the more likely the subject is a control rather than TUC or TUP breast cancer case

some genes that demonstrated differential methylation levels between the two tumour zones. This was true not only for both cancer specific genes (genes that were shown to be specifically methylated in the breast tumour tissue when they were compared with the controls) but also for the genes that were shown to be non-specifically methylated in cancer. In order to verify these results we performed non-parametric paired test for the genes one by one. The $p$ values for each gene, suggested that there was no difference in the methylation level between the two zones within the tumour for cancer specific genes (Table 6) and non-cancer specific genes (supplemental Table S4). In order to investigate whether there is any correlation between the two different zones, we performed Spearman correlation analysis. The analysis showed 4 out of the 13 genes to be positively correlated in both the training and validation for the two different zones of the tumour (Table 6).

\section{Discussion}

Over the last few years, the role of DNA methylation in cancer has been the subject of many studies and it is 
Table 4 Percentage of positive cases and distribution of methylation levels of the 13 genes tested in validation set

\begin{tabular}{|c|c|c|c|c|c|c|c|c|c|}
\hline \multirow[t]{2}{*}{ Genes } & \multicolumn{2}{|c|}{ Controls $(n=18)$} & \multicolumn{3}{|c|}{ TUC $(n=19)$} & \multicolumn{4}{|c|}{ TUP $(n=20)$} \\
\hline & Positive $(\%)$ & Median PMR & Positive (\%) & Median PMR & $p$ value & Positive $(\%)$ & Median PMR & $p$ value & $p$ value (rank) \\
\hline HOXA1 & 44.40 & 0.00 & 94.70 & 26.15 & 0.000 & 89.50 & 25.54 & 0.000 & 3 \\
\hline$G A D 1$ & 100 & 0.78 & 100 & 15.00 & 0.000 & 94.70 & 14.72 & 0.000 & 2 \\
\hline HOXА13 & 38.90 & 0.00 & 94.70 & 152.61 & 0.000 & 84.20 & 126.08 & 0.000 & 5 \\
\hline$C R A B P 1$ & 0 & - & 73.70 & 5.16 & 0.000 & 57.90 & 3.12 & 0.000 & 7 \\
\hline NEUROD1 & 44.40 & 0.00 & 89.50 & 9.73 & 0.000 & 89.50 & 6.51 & 0.000 & 4 \\
\hline HOXD9 & 100 & 0.24 & 100 & 8.02 & 0.000 & 100 & 1.84 & 0.002 & 10 \\
\hline PITX2 (II) & 38.90 & 0.00 & 84.20 & 5.69 & 0.000 & 84.20 & 4.25 & 0.000 & 6 \\
\hline HOXD11 & 66.70 & 0.10 & 94.70 & 39.07 & 0.000 & 84.20 & 32.94 & 0.001 & 9 \\
\hline$T M E F F 2$ & 83.30 & 0.15 & 89.50 & 22.34 & 0.000 & 100 & 16.57 & 0.000 & 1 \\
\hline PENK & 22.20 & 0.00 & 68.40 & 0.29 & 0.001 & 73.70 & 0.85 & 0.000 & 8 \\
\hline HOXА7 & 100 & 1.86 & 94.70 & 6.22 & 0.004 & 100 & 4.31 & 0.025 & 12 \\
\hline HOXD12 & 66.70 & 0.17 & 78.90 & 4.98 & 0.006 & 89 & 6.97 & 0.002 & 11 \\
\hline MT1A & 100 & 73.06 & 100 & 37.55 & 0.023 & 100 & 46.07 & 0.027 & 13 \\
\hline
\end{tabular}

TUP Tumour taken from the centre, TUP Tumour taken from the periphery, PMR Percentage of methylated reference

Controls and breast cancer cases (TUC and TUP) showing the percentage of positive cases and the median PMR values. $p$ values are provided from Mann-Whitney test for each gene. Significance required a $p$ value of less than 0.05 after Mann-Whitney test

Table 5 ROC analysis for both TUC and TUP in validation set

\begin{tabular}{|c|c|c|c|c|c|c|c|c|c|}
\hline \multirow[t]{2}{*}{ Genes } & \multicolumn{4}{|l|}{ TUC } & \multicolumn{5}{|l|}{ TUP } \\
\hline & AUC & $95 \%$ CI lower & $95 \%$ CI upper & $p$ value & AUC & $95 \%$ CI lower & $95 \%$ CI upper & $p$ value & Rank \\
\hline$H O X D 9$ & 0.889 & 0.787 & 0.991 & 0.000 & 0.801 & 0.659 & 0.944 & 0.002 & 9 \\
\hline HOXA7 & 0.778 & 0.626 & 0.930 & 0.004 & 0.716 & 0.551 & 0.881 & 0.025 & 12 \\
\hline$T M E F F 2$ & 0.860 & 0.722 & 0.997 & 0.000 & 0.977 & 0.936 & 1.017 & 0.000 & 1 \\
\hline PENK & 0.792 & 0.642 & 0.943 & 0.002 & 0.822 & 0.68 & 0.963 & 0.001 & 8 \\
\hline HOXA1 & 0.950 & 0.872 & 1.029 & 0.000 & 0.901 & 0.788 & 1.014 & 0.000 & 3 \\
\hline$M T 1 A^{*}$ & 0.719 & 0.111 & 0.450 & 0.020 & 0.713 & 0.637 & 0.942 & 0.027 & 13 \\
\hline HOXD11 & 0.883 & 0.767 & 0.999 & 0.000 & 0.825 & 0.679 & 0.971 & 0.001 & 7 \\
\hline HOXD12 & 0.760 & 0.598 & 0.923 & 0.007 & 0.789 & 0.638 & 0.941 & 0.003 & 11 \\
\hline$G A D 1$ & 0.936 & 0.853 & 1.018 & 0.000 & 0.918 & 0.81 & 1.026 & 0.000 & 2 \\
\hline NEUROD1 & 0.904 & 0.795 & 1.012 & 0.000 & 0.892 & 0.78 & 1.004 & 0.000 & 4 \\
\hline HOXА13 & 0.925 & 0.837 & 1.014 & 0.000 & 0.858 & 0.729 & 0.987 & 0.000 & 5 \\
\hline PITX2 (II) & 0.876 & 0.752 & 0.999 & 0.000 & 0.852 & 0.723 & 0.981 & 0.000 & 6 \\
\hline$C R A B P 1$ & 0.868 & 0.742 & 0.994 & 0.000 & 0.789 & 0.637 & 0.942 & 0.003 & 10 \\
\hline
\end{tabular}

ROC Receiver operating characteristic, AUC Area under the curve, TUP Tumour taken from the periphery, TUC Tumour taken from the centre, CI Confidence interval

The performance of each gene as a predictor of cancer was assessed using ROC curves and the AUC value. The significant assessment required a $p$ value of less than 0.05 . The genes were ordered according to the rank of the $p$ value for the test of TUC and TUP versus control

* 'Reverse decision rule' applied means that the higher the methylation value, the more likely the subject is a control rather than TUC or TUP cancer case

generally accepted that methylation of gene promoters is associated with gene silencing. However, as accumulating evidence suggests that DNA methylation can occur at loci without an effect on gene expression, we wanted to investigate the correlation between NEUROD1 methylation and expression. Based on this analysis no association between DNA methylation and gene expression was found. These data are in agreement with previous reports suggesting that PCGT genes with tumour-specific promoter DNA methylation are not normally expressed in the 
Table 6 Comparison of DNA methylation changes between TUC and TUP with non-parametric paired test and Spearman correlation analysis

\begin{tabular}{llcl}
\hline Genes & $\begin{array}{l}\text { Non-parametric paired test } \\
p \text { value }\end{array}$ & \multicolumn{2}{c}{$\begin{array}{l}\text { Spearman correlation coefficient } \\
p \text { value }\end{array}$} \\
\hline HOXD9 & 0.675 & 0.339 & 0.054 \\
HOXA7 & 0.993 & 0.120 & 0.507 \\
PENK & 0.766 & 0.110 & 0.544 \\
TMEFF2 & 0.280 & 0.399 & 0.021 \\
HOXA1 & 0.614 & 0.347 & 0.048 \\
MT1A & 0.714 & 0.675 & 0.000 \\
CRABP1 & 0.715 & 0.567 & 0.001 \\
HOXD11 & 0.822 & 0.313 & 0.077 \\
HOXD12 & 0.217 & 0.216 & 0.227 \\
NEUROD1 & 0.814 & 0.361 & 0.039 \\
GAD1 & 0.526 & 0.266 & 0.135 \\
HOXA13 & 0.382 & -0.035 & 0.847 \\
PITX2 (II) & 0.829 & 0.256 & 0.151
\end{tabular}

TUP Tumour taken from the periphery, TUC Tumour taken from the centre

$p$ values are given from the 13 genes that were further confirmed in the validation set. Non-parametric paired test analysis comparing the rank order of values for TUC versus TUP to assess if there is a difference in their methylation levels and correlation coefficient analysis is also demonstrated

epithelium of the tumour. It also provides further evidence on our previous published data that DNA methylation of PCGT genes in cancer may result in a residual stem-cell memory rather than a selective pressure for silencing these particular genes during carcinogenesis [30].

Therefore, based on the following three observations: (1) there is no relationship between NEUROD1 methylation and expression levels (2) lack of NEURODI expression in the majority of the samples tested and (3) published findings that methylation of PCGT genes is a promising target for marker identification [27, 30-32], we wanted to further examine the predictive role of these genes in breast cancer and to examine whether they are affected by intra-tumour heterogeneity. MethyLight analysis of PCGT genes identified a constant panel of genes to be methylated in both central and peripheral tumour samples compared with controls, and non-parametric paired analysis indicated that there was no statistical significant difference between the methylation levels of the two zones within the cancer. This was true for both breast cancer specific genes and genes that were not specifically methylated in cancer. In order to investigate whether there is an association between the methylation changes observed in the two different tumour tissues, we performed correlation analysis showing 4 out of 13 genes to be positive associated.

NEUROD1 was one of the genes that did not show statistically significant differences in the methylation levels between TUC and TUP, suggesting it is homogeneously methylated within the tumour. This is an important finding as it further supports our previous report that NEURODI methylation could be a good predictive marker in breast cancer as it is not affected by intra-tumour heterogeneity [27]. Moreover, this study provides further evidence for paired-like homeodomain transcription factor 2 (PITX2) which has been shown by Harbeck et al. [37] to be a good biomarker for breast cancer hormone therapy treatment and, having performed analysis of several different tissue sections, has also shown a low variability in methylation measurements.

To our knowledge there is no other study that has examined breast cancer intra-tumour heterogeneity and its effect on DNA methylation changes. In contrast, there are two studies analysing expression modifications in correlation to intra-tumour heterogeneity. Both were carried on micro-dissected tumour cells rather than core biopsies. The first study by Aubele et al. [14] confirmed heterogeneity by comparative genomic hybridization. The second study by Zhu et al. [15] described expression heterogeneity in sections that were obtained from morphologically dissimilar regions, one from the centre containing invasive breast tumourigenic cells, and the other from the periphery containing ductal carcinoma in situ (DCIS). The differences in the expression profile described in this study could be attributed to the different type of cells analysed i.e. comparing invasive with non-invasive cells. Our finding that methylated PCGT genes provide reliable data irrespective of sampling topography, suggests that methylation analysis of these genes could hold great potential for improving breast cancer management. In addition, we have also demonstrated that the technology for methylation analysis 
can be easily applied in clinical routine as only a core biopsy would be required instead of purified cell population of cells.

Our results are in contrast to reports of DNA methylation changes of different candidate genes in other cancer types which have been shown to be affected by intratumour heterogeneity. In melanoma, when methylation changes and expression status of suppressor genes were analysed, tissue taken from the centre of the tumour found to represent the whole tumour more accurately than the tissue from the periphery $[38,39]$. A more recent study of ovarian cancer suggested that both inter- and intra-tumour heterogeneity are allied with $N Y$-ESO- 1 expression, which was correlated with promoter and global DNA-methylation alterations when micro-dissected cells were analysed [40]. Further studies are required before it can be determined whether these changes are cancer or gene specific.

In this study, we have identified and confirmed in the validation set, 13 PCGTs that can predict breast cancer. This includes the first report of hypermethylation of the transmembrane protein with EGF-like and two follistatin-like domains 2 (TEMFF2), the proenkephalin (PENK), glutamate decarboxylase-1 (GADI) and cellular retinoic acid binding protein 1 (GRABPl) genes in breast cancer. Even though the role of TMEFF2 gene methylation has been observed in other types of cancer such as colorectal, bladder $[41,42]$ and gastric adenocarcinomas [43], there are no reports for breast cancer. PENK gene expression has been shown to be down regulated in prostate and bladder cancer using, expression profiling [44]. Methylation of GADl has not been previously shown to be associated with cancer and $C R A B P 1$ methylation was only reported in association with colon [45] and ovarian [46] cancer. In contrast, there are reports of an association between methylation of PITX2 and metallothionein 1A (MTIA) with breast carcinogenesis, further validating the data presented [37, 47].

Interestingly, 6 of the 13 methylated loci we identified are genes belonging to the homeobox (HOX) domain. These genes are known to control normal development and differentiation of many multi-cellular organisms [48]. For more than a decade the role of the HOX domain in carcinogenesis has also been highlighted. An example is HOXB7 which has been implicated as an oncogene and is known to increase the expression of basic fibroblast growth factor $(b F G F)$ in melanoma [49]. Indeed, previous data has confirmed that $H O X$ gene cluster methylation is a common feature in cancer [50] including breast cancer [25, 51]. In the search for more specific and sensitive markers, a recent study by Fiegl et al. [52] has shown that HOXAll is methylated in ovarian cancer and a marker indicating poor prognosis.

It is worth mentioning despite the small sample size used in this study, our results are consistent and identified cancer specifically methylated genes characterized by high AUC values indicating a high sensitivity and specificity compared with studies that have used larger sample sizes [25].

For future work we plan to investigate methylation profiles of metastatic specimens compared with matched primary tissues in order to examine whether DNA methylation of PCGT genes is homogeneous in breast cancer metastases. A recent study by Wu et al. [53] demonstrated that samples taken from a patient's primary breast carcinoma and their metastatic breast cancer are characterized by extensive expression heterogeneity. The study confirmed that ER and/or PR status characterizing the primary cancer may be lost in the metastatic carcinoma. This observation is important as the metastasis will not be hormone sensitive as its primary carcinoma resulting in resistance to the therapy. Interestingly the methylation signature of the primary tumour tissue compared with the metastatic specimen was similar, with the latter only exhibiting a higher intensity of methylation.

This is a proof of principle study demonstrating for the first time that methylation of PCGT genes is unaffected by intratumour heterogeneity within a set of breast cancer samples. These findings suggest that methylation of specifically identified PCGT genes may present a more robust means with which to guide breast cancer management, particularly in instances when only small core biopsies are available for assessment. Further investigation of epigenetic intra-tumour heterogeneity within breast cancer, as well as other cancer types is necessary; nonetheless evidence is beginning to accumulate in recognition of the potential of DNA methylation markers in cancer assessment and treatment.

Acknowledgments The work described in this manuscript was supported by The Eve Appeal, the Jubilaeumsfonds der Oesterreichischen Nationalbank, project no. 11992 and a grant from the European Union (FP6-016467, Biognosis).

\section{References}

1. Feuer EJ, Wun LM, Boring CC et al (1993) The lifetime risk of developing breast cancer. J Natl Cancer Inst 85:892-897. doi:10.1093/jnci/85.11.892

2. Kok M, Linn SC, Van Laar RK, Jansen MP, van den Berg TM, Delahaye LJ, Glas AM, Peterse JL, Hauptmann M, Foekens JA, Klijn JG, Wessels LF, Van't Veer LJ, Berns EM (2009) Comparison of gene expression profiles predicting progression in breast cancer patients treated with tamoxifen. Breast Cancer Res Treat 113:275-283. doi:10.1007/s10549-008-9939-y

3. Lu X, Lu X, Wang ZC, Iglehart JD, Zhang X, Richardson AL (2008) Predicting features of breast cancer with gene expression patterns. Breast Cancer Res Treat 108:191-201. doi:10.1007/ s10549-007-9596-6

4. Yang SX, Steinberg SM, Nguyen D, Wu TD, Modrusan Z, Swain SM (2008) Gene expression profile and angiogenic marker 
correlates with response to neoadjuvant bevacizumab followed by bevacizumab plus chemotherapy in breast cancer. Clin Cancer Res 14:5893-5899. doi:10.1158/1078-0432.CCR-07-4762

5. Chanrion M, Negre V, Fontaine H, Salvetat N, Bibeau F, Mac Grogan G, Mauriac L, Katsaros D, Molina F, Theillet C, Darbon JM (2008) A gene expression signature that can predict the recurrence of tamoxifen-treated primary breast cancer. Clin Cancer Res 14:1744-1752. doi:10.1158/1078-0432.CCR-07-1833

6. Michiels S, Koscielny S, Hill C (2005) Prediction of cancer outcome with microarrays: a multiple random validation strategy. Lancet 365:488-492. doi:10.1016/S0140-6736(05)17866-0

7. Heppner GH (1984) Tumor heterogeneity. Cancer Res 44:22592265

8. Khalique L, Ayhan A, Weale ME, Jacobs IJ, Ramus SJ, Gayther SA (2007) Genetic intra-tumor heterogeneity in epithelial ovarian cancer and its implications for molecular diagnosis of tumors. J Pathol 211:286-295. doi:10.1002/path.2112

9. Losi L, Baisse B, Bouzourene H, Benhattar J (2005) Evolution of intra-tumoral genetic heterogeneity during colorectal cancer progression. Carcinogenesis 26:916-922. doi:10.1093/carcin/bgi044

10. Lyng MB, Laenkholm AV, Pallisgraad N et al (2007) Intra-tumor genetic heterogeneity in advanced carcinomas as determined by fine needle aspiration and TaqMan low density array. Cell Oncol 29:361-372

11. Ruiz-Cerda JL, Hernandez M, Sempere A, O'Connor JE, Kimler BF, Jimenez-Cruz F (1999) Intra-tumoral heterogeneity of DNA content in renal cell carcinoma and its prognostic significance. Cancer 86:664-671. doi:10.1002/(SICI)1097-0142(19990815) 86:4<664::AID-CNCR16>3.0.CO;2-E

12. van der Poel HG, Oosterhof GO, Schaafsma HE, Debruyne FM, Schalken JA (1997) Intra-tumoral nuclear morphologic heterogeneity in prostate cancer. Urology 49:652-657. doi:10.1016/ S0090-4295(96)00557-2

13. Lyng H, Beigi M, Svendsrud DH, Brustugun OT, Stokke T, Kristensen GB, Sundfor K, Skjonsberg A, De Angelis PM (2004) Intra-tumor chromosomal heterogeneity in advanced carcinomas of the uterine cervix. Int J Cancer 111:358-366. doi:10.1002/ ijc. 20258

14. Aubele M, Mattis A, Zitzelsberger H, Walch A, Kremer M, Hutzler P, Hofler H, Werner M (1999) Intra-tumoral heterogeneity in breast carcinoma revealed by laser-microdissection and comparative genomic hybridization. Cancer Genet Cytogenet 110:94-102. doi:10.1016/S0165-4608(98)00205-2

15. Zhu G, Reynolds L, Crnogorac-Jurcevic T, Gillett CE, Dublin EA, Marshall JF, Barnes D, D'Arrigo C, Van Trappen PO, Lemoine NR, Hart IR (2003) Combination of microdissection and microarray analysis to identify gene expression changes between differentially located tumor cells in breast cancer. Oncogene 22:3742-3748. doi:10.1038/sj.onc.1206428

16. Nakamura T, Kuwai T, Kitadai Y, Sasaki T, Fan D, Coombes KR, Kim SJ, Fidler IJ (2007) Zonal heterogeneity for gene expression in human pancreatic carcinoma. Cancer Res 67:75977604. doi:10.1158/0008-5472.CAN-07-0874

17. Sigalotti L, Coral S, Nardi G, Spessotto A, Cortini E, Cattarossi I, Colizzi F, Altomonte M, Maio M (2002) Promoter methylation controls the expression of MAGE2, 3 and 4 genes in human cutaneous melanoma. J Immunother 25:16-26. doi:10.1097/ 00002371-200201000-00002

18. Kuniyasu H, Troncoso P, Johnston D, Bucana CD, Tahara E, Fidler IJ, Pettaway CA (2000) Relative expression of type IV collagenase, E-cadherin, and vascular endothelial growth factor/ vascular permeability factor in prostatectomy specimens distinguishes organ-confined from pathologically advanced prostate cancers. Clin Cancer Res 6:2295-2308

19. Jarque F, Lluch A, Vera FJ, Pascual A, Vizcarra E, Alberola V, Garcia-Conde J (1990) Intra-tumoral variation of estrogen and progesterone receptors in breast cancer: relationship with histopathological characteristics of the tumor. Oncology 47:9-13

20. Davis BW, Zava DT, Locher GW, Goldhirsch A, Hartmann WH (1984) Receptor heterogeneity of human breast cancer as measured by multiple intratumoral assays of estrogen and progesterone receptor. Eur J Cancer Clin Oncol 20:375-382. doi:10.1016/02775379(84)90084-1

21. van Notten JP, Armstrong JB, Caryle SS, Goodchild NL, Thornton IG, Brigden ML, Coy P, Fletcher C (1988) Estrogen receptor distribution in the peripheral, intermediate and central regions of breast cancer. Eur J Cancer Clin Oncol 24:1885-1889. doi:10.1016/0277-5379(88)90102-2

22. Baylin SB, Ohm JE (2006) Epigenetic gene silencing in cancera mechanism for early oncogenic pathway addiction? Nat Rev Cancer 6:107-116. doi:10.1038/nrc1799

23. Feinberg AP, Tycko B (2004) The history of cancer epigenetics. Nat Rev Cancer 4:143-153. doi:10.1038/nrc1279

24. Widschwendter M, Jones PA (2002) DNA methylation and breast carcinogenesis. Oncogene 21:5462-5482. doi:10.1038/sj.onc. 1205606

25. Ordway JM, Budiman MA, Korshunova Y, Maloney RK, Bedell JA, Citek RW, Bacher B, Peterson S, Rohlfing T, Hall J, Brown R, Lakey N, Doerge RW, Martienssen RA, Leon J, McPherson JD, Jeddeloh JA (2007) Identification of novel high-frequency DNA methylation changes in breast cancer. PLoS ONE 2:e1314. doi:10.1371/journal.pone.0001314

26. Widschwendter M, Siegmund KD, Muller HM, Fiegl H, Marth C, Muller-Holzner E, Jones PA, Laird PW (2004) Association of breast cancer DNA methylation profiles with hormone receptor status and response to tamoxifen. Cancer Res 64:3807-3813. doi:10.1158/0008-5472.CAN-03-3852

27. Fiegl H, Jones A, Hauser-Kronberger C, Hutarew G, Reitsamer R, Jones RL, Dowsett M, Mueller-Holzner E, Windbichler G, Daxenbichler G, Goebel G, Ensinger C, Jacobs I, Widschwendter M (2008) Methylated NEUROD1 promoter is a marker for chemosensitivity in breast cancer. Clin Cancer Res 14:34943502. doi:10.1158/1078-0432.CCR-07-4557

28. Pakneshan P, Têtu B, Rabbani SA (2004) Demethylation of urokinase promoter as a prognostic marker in patients with breast carcinoma. Clin Cancer Res 10:3035-3041. doi:10.1158/10780432.CCR-03-0545

29. Chung W, Kwabi-Addo B, Ittmann M, Jelinek J, Shen L, Yu Y, Issa JP (2008) Identification of novel tumor markers in prostate, colon and breast cancer by unbiased methylation profiling. PLoS ONE 30:e2079. doi:10.1371/journal.pone.0002079

30. Widschwendter M, Fiegl H, Egle D, Mueller-Holzner E, Spizzo G, Marth C, Weisenberger DJ, Campan M, Young J, Jacobs I, Laird PW (2007) Epigenetic stem cell signature in cancer. Nat Genet 39:157-158. doi:10.1038/ng1941

31. Ohm JE, McGarvey KM, Yu X, Cheng L, Schuebel KE, Cope L, Mohammad HP, Chen W, Daniel VC, Yu W, Berman DM, Jenuwein T, Pruitt K, Sharkis SJ, Watkins DN, Herman JG, Baylin SB (2007) A stem cell-like chromatin pattern may predispose tumor suppressor genes to DNA hypermethylation and heritable silencing. Nat Genet 39:237-242. doi:10.1038/ng1972

32. Schlesinger Y, Straussman R, Keshet I, Farkash S, Hecht M, Zimmerman J, Eden E, Yakhini Z, Ben Shushan E, Reubinoff BE, Bergman Y, Simon I, Cedar H (2007) Polycomb-mediated methylation on Lys 27 of histone $\mathrm{H} 3$ pre-marks genes for de novo methylation in cancer. Nat Genet 39:232-236. doi:10.1038/ng1950

33. Eads CA, Danenberg KD, Kawakami K, Saltz LB, Blake C, Shibata D, Danenberg PV, Laird PW (2000) MethyLight: a highthroughput assay to measure. Nucleic Acids Res 28:E32. doi:10.1093/nar/28.8.e32

34. Widschwendter M, Berger J, Hermann M, Müller HM, Amberger A, Zeschnigk M, Widschwendter A, B Abendstein, Zeimet AG, 
Daxenbichler G, Marth C (2000) Methylation and silencing of the retinoic acid receptor-beta2 gene in breast cancer. J Natl Cancer Inst 92:826-832. doi:10.1093/jnci/92.10.826

35. Muller HM, Fiegl H, Goebel G, Hubalek MM, Widschwendter A, Muller-Holzner E, Marth C, Widschwendter M (2003) MeCP2 and MBD2 expression in human neoplastic and non-neoplastic breast tissue and its association with oestrogen receptor status. $\mathrm{Br}$ J Cancer 89:1934-1939. doi:10.1038/sj.bjc.6601392

36. Bieche I, Franc B, Vidaud D, Vidaud M, Lidereau R (2001) Analyses of MYC, ERBB2, and CCND1 genes in benign and malignant thyroid follicular cell tumors by real-time polymerase chain reaction. Thyroid 11:147-152. doi:10.1089/105072501 300042802

37. Harbeck N, Nimmrich I, Hartmann A, Ross JS, Cufer T, Grutzmann R, Kristiansen G, Paradiso A, Hartmann O, Margossian A, Martens J, Schwope I, Lukas A, Muller V, Milde-Langosch K, Nahrig J, Foekens J, Maier S, Schmitt M, Lesche, R Multicenter Study (2008) Using paraffin-embedded tumor tissue testing PITX2 DNA methylation as a marker for outcome prediction in tamoxifen-treated, node-negative breast cancer patients. J Clin Oncol 28:5036-5042. doi:10.1200/JCO.2007.14.1697

38. Sigalotti L, Fratta E, Coral S, Tanzarella S, Danielli R, Colizzi F, Fonsatti E, Traversari C, Altomonte M, Maio M (2004) Intratumor heterogeneity of cancer/testis antigens expression in human cutaneous melanoma is methylation-regulated and functionally reverted by 5 -aza-2'-deoxycytidine. Cancer Res 64: 9167-9171. doi:10.1158/0008-5472.CAN-04-1442

39. Rastetter M, Schagdarsurengin U, Lahtz C, Fiedler E, Marsch WC, Dammann R, Helmbold P (2007) Frequent intra-tumoral heterogeneity of promoter hypermethylation in malignant melanoma. Histol Histopathol 22:1005-1015

40. Woloszynska-Read A, Mhawech-Fauceglia P, Yu J, Odunsi K, Karpf AR (2008) Intertumor and intratumor NY-ESO-1 expression heterogeneity is associated with promoter-specific and global DNA methylation status in ovarian cancer. Clin Cancer Res 14:3283-3290. doi:10.1158/1078-0432.CCR-07-5279

41. Ebert MP, Mooney SH, Tonnes-Priddy L, Lograsso J, Hoffmann J, Chen J, Rocken C, Schulz HU, Malfertheiner P, Lofton-Day C (2005) Hypermethylation of the TPEF/HPP1 gene in primary and metastatic colorectal cancers. Neoplasia 7:771-778. doi:10.1593/ neo.05235

42. Liang G, Robertson KD, Talmadge C, Sumagi J, Jones PA (2000) The gene for a novel transmembrane protein containing epidermal growth factor and follistatin domains is frequently hypermethylated in human tumor cells. Cancer Res 60:49074912

43. Shibata DM, Sato F, Mori Y, Perry K, Yin J, Wang S, Xu Y, Olaru A, Selaru F, Spring K, Young J, Abraham JM, Meltzer SJ
(2002) Hypermethylation of HPP1 is associated with hMLH1 hypermethylation in gastric adenocarcinomas. Cancer Res 62: $5637-5640$

44. Goo YA, Goodlett DR, Pascal LE, Worthington KD, Vessella RL, True LD, Liu AY (2005) Stromal mesenchyme cell genes of the human prostate and bladder. BMC Urol 5:17. doi:10.1186/ 1471-2490-5-17

45. Lind GE, Kleivi K, Meling GI, Teixeira MR, Thiis-Evensen E, Rognum TO, Lothe RA (2006) ADAMTS1, CRABP1, and NR3C1 identified as epigenetically deregulated genes in colorectal tumorigenesis. Cell Oncol 28:259-272

46. Wu Q, Lothe RA, Ahlquist T, Silins I, Tropé CG, Micci F, Nesland JM, Suo Z, Lind GE (2007) DNA methylation profiling of ovarian carcinomas and their in vitro models HOXA9, HOXB5, SCGB3A1 as novel targets. Mol Cancer 6:45-55. doi: 10.1186/1476-4598-6-45

47. Piotrowski A, Benetkiewicz M, Menzel U, de Ståhl TD, Mantripragada K, Grigelionis G, Buckley PG, Jankowski M, Hoffman J, Bała D, Srutek E, Laskowski R, Zegarski W, Dumanski JP (2006) Microarray-based survey of $\mathrm{CpG}$ islands identifies concurrent hyper- and hypomethylation patterns in tissues derived from patients with breast cancer. Genes Chromosomes Cancer 45:656-667. doi:10.1002/gcc.20331

48. Pearson JC, Lemons D, McGinnis W (2006) Modulating Hox gene functions during animal body patterning. Nat Rev Genet 6:893-904. doi:10.1038/nrg 1726

49. Caré A, Silvavi A, Meccia E, Mattia G, Stoppacciaro A, Parmiani G, Peschle C, Colombo MP (1996) HOXB7 constitutively activates basic fibroblast growth factor in melanomas. Mol Cell Biol $16: 4842-4851$

50. Chen H, Sukumar S (2003) HOX genes: emerging stars in cancer. Cancer Biol Ther 2:524-525

51. Novak P, Jensen T, Oshiro MM, Wozniak RJ, Nouzova M, Watts GS, Klimecki WT, Kim C, Futscher BW (2006) Epigenetic inactivation of the HOXA gene cluster in breast cancer. Cancer Res 66:10664-10670. doi:10.1158/0008-5472.CAN-06-2761

52. Fiegl H, Windbichler G, Mueller-Holzner E, Goebel G, Lechner M, Jacobs IJ, Widschwendter M (2008) HOXA11 DNA methylation-a novel prognostic biomarker in ovarian cancer. Int $\mathbf{J}$ Cancer 123:725-729. doi:10.1002/ijc.23563

53. Wu JM, Fackler MJ, Halushka MK, Molavi DW, Taylor ME, Teo WW, Griffin C, Fetting J, Davidson NE, De Marzo AM, Hicks JL, Chitale D, Ladanyi M, Sukumar S, Argani P (2008) Heterogeneity of breast cancer metastases: comparison of therapeutic target expression and promoter methylation between primary tumors and their multifocal metastases. Clin Cancer Res 7:19381946. doi:10.1158/1078-0432.CCR-07-4082 